\title{
6 \\ Implementasi Metode Fuzzy Time Series Cheng untuk prediksi Kosentrasi Gas NO2 Di Udara
}

\author{
M Yoka Fathoni *) \\ Politeknik Harapan Bersama Tegal
}

Naskah Diterima : 7 September 2016; Diterima Publikasi :29 April 2017

DOI : $10.21456 /$ vol7iss1pp17-23

\begin{abstract}
The forecasting process is essential for determining air quality to monitor NO2 gas in the air. The research aims to develop prediction information system of NO2 gas in air. The method used is Fuzzy Time Series Cheng method. The process of acquiring NO2 gas data is integrated with Multichannel-Multistasion. The data acquisition process uses Wireless Sensor Network technology via broadband internet that is sent and stored in an online database form on the web server. Recorded data is used as material for prediction. Acquisition result of NO2 gas data is obtained from the sensor which is sent to the web server in the data base in the network by on line, then for futher it is predicted using fuzzy time series Cheng applying re-divide to the results of intervals the first partition of the value of the universe of discourse by historical data fuzzification to determine Fuzzy Logical Relationship dan Fuzzy Logical Relationship Group, so that is obtained result value prediction of $\mathrm{NO} 2$ gas concentration. By using 36 sample data of NO2 gas, it is obtained that the value of root of mean squared error of $2.08 \%$. This result indicates that the method of Fuzzy Time Series Cheng is good enough to be used in predicting the NO2 gas.
\end{abstract}

Keywords: Fuzzy Time Series Cheng; Fuzzy Time Series Cheng; gas $\mathrm{NO}_{2}$

\begin{abstract}
Abstrak
Proses peramalan sangat penting untuk penentuan kualitas udara untuk memantau gas $\mathrm{NO}_{2}$ di udara. Penelitian ini bertujuan mengembangkan sistem informasi prediksi gas $\mathrm{NO}_{2}$ di udara. Metode yang digunakan adalah metode Fuzzy Time Series Cheng. Proses akuisisi data gas $\mathrm{NO}_{2}$ terintegrasi dengan Multichannel-Multistasion. Proses akuisi data ini menggunakan teknologi Wireless Sensor Network melalui internet broadband yang dikirimkan dan disimpan dalam bentuk online database pada web server. Data yang terekam digunakan sebagai bahan untuk prediksi. Data gas $\mathrm{NO}_{2}$ hasil akuisisi diperoleh dari sensor yang dikirim ke web server dalam basis data dalam jaringan secara online untuk selanjutnya di prediksi menggunakan Fuzzy Time Series Cheng yang menerapkan pembagian ulang terhadap hasil interval partisi pertama dari nilai semesta pembicaraandengan melakukan fuzzifikasi data historis untuk menentukan Fuzzy Logical Relationship dan Fuzzy Logical Relationship Group, sehingga didapat hasil nilai prediksi konsentrasi gas $\mathrm{NO}_{2}$. Dengan menggunakan 36 data sampel dari gas $\mathrm{NO}_{2}$, diperoleh nilai root of mean squared error sebesar $2.08 \%$. Hal ini mengindikasikan bahwa metode Fuzzy Time Series Cheng adalah cukup baik untuk digunakan dalam memprediksi Gas $\mathrm{NO}_{2}$.
\end{abstract}

Kata Kunci : Fuzzy Time Series Cheng; Fuzzy Time Series Cheng; gas $\mathrm{NO}_{2}$

\section{Pendahuluan.}

Prediksi Data runtun waktu (time series) adalah jenis data yang dikumpulkan menurut urutan waktu dalam suatu rentang waktu tertentu. Analisis data runtun waktu merupakan salah satu prosedur statistika yang diterapkan untuk meramalkan struktur probabilitas keadaan yang akan datang dalam rangka pengambilan keputusan. Pemodelan time series dapat untuk memprediksi kecenderungan perkembangan atau perubahan suatu obyek dimasa mendatang dengan memanfaatkan data yang telah ada. Pemodelan tersebut telah digunakan untuk antara lain model prediksi perubahan harga saham, penjualan produk atau bahkan produktifitas lahan pertanian.

Fuzzy Time Series (FTS) telah diterapkan untuk memecahkan berbagai domain masalah prediksi seperti prediksi keuangan, penerimaan mahasiswa, prediksi temperatur udara dan lain-lainnya (Cheng et

*) Penulis korespondensi: myokafathoni@gmail.com 
al.,, 2008). Hal lain yang menjadi keunggulan permodelan FTS dibandingkan dengan fuzzy konvensional yaitu adanya data historis. Pada FTS yang digunakan adalah himpunan fuzzy sebagai suatu kelas bilangan dengan batasan yang samar, atau dengan kata lain, prediksi dalam sistem fuzzy yang digunakan bukan nilai riil melainkan nilai linguistik. Dengan kata lain metode FTS tidak hanya bergantung pada asumsi data stasioner terhadap ragam ataupun rata-rata, sedangkan metode time series konvensional lainnya membutuhkan lebih banyak data historis yang menyebar normal (Chen et al.,, 2007).

Dengan semakin diperlukannya informasi terkait dengan kualitas udara termasuk di dalamnya $\mathrm{NO}_{2}$ (Nitrogen Dioksida) maka prediksi perubahan kandungan $\mathrm{NO}_{2}$ di udara akan sangat berguna seperti halnya prediksi cuaca yang akan memberikan dampak yang luas (Zang et al.,, 2012). Gas $\mathrm{NO}_{2}$ apabila mencemari udara dapat diamati dari baunya yang sangat menyengat dan warnanya yang merah kecoklatan. Sifat racun gas $\mathrm{NO}_{2}$ empat kali lebih kuat dari pada gas NO (Nitrogen Monoksida). Di udara yang normal, NO dapat mengalami oksidasi menjadi $\mathrm{NO}_{2}$ yang bersifat racun dan apabila terpapar dalam dosis yang tinggi memperlihatkan gejala kelumpuhan sistim syarat dan kekejangan serta pembengkakan paru (edema pulmonari) yang dapat menyebabkan kematian. Selain sangat berbahaya bagi manusia, $\mathrm{NO}_{2}$ diyakini berperan utama dalam hal penurunan jumlah ozon di atmosfir serta penyebab utama hujan asam (Vanalakar et al., 2015). Berbagai penelitian yang berkaitan dengan prediksi kandungan $\mathrm{NO}_{2}$ antara lain penelitian penilaian kinerja dari sistem prediksi kualitas udara resolusi tingkat tinggi (Aguilera et al.,, 2013). Penelitian lain adalah prediksi emisi Volatile organic compounds (VOC) yang salah satu unsur didalamnya adalah $\mathrm{NO}_{2}$ pada lalu lintas dan industri dengan menerapkan Classification and Regression Multivariate Method (Stojic et al.,, 2015).

Penelitian ini bertujuan mengembangkan sistem informasi prediksi gas $\mathrm{NO}_{2}$ di udara. Metode yang digunakan adalah metode Fuzzy Time Series Cheng. Proses akuisisi data gas $\mathrm{NO}_{2}$ terintegrasi dengan Multichannel-Multistasion. Penggunaan FTS dengan Time Invariant menunjukkan bahwa perbedaan penyimpangan prediksi relative lebih kecil seiring dengan penambahan waktu. Hal ini menunjukkan bahwa permodelan FTS dengan Time Invariant memiliki keunggulan karena pengalaman dan ilmu pengetahuan manusia telah dimasukkan ke dalam permodelan meskipun data historikal yang dimiliki kurang akurat (Song et al.,, 1993).

\section{Kerangka teori}

Pengembangan sistem informasi preditiksi untuk gas CO2 menggunakan modelan Fuzzy Time Series
Cheng. Algoritma prediksi menggunakan model Fuzzy Time Series Cheng dilakukan dengan tahapan sebagai berikut :

Langkah 1: Mendefinisikan himpunan semesta (universe discourse) $\mathrm{U}$ dari data historical.

Langkah 2: Membagi himpunan semesta $U$ ke dalam beberapa interval yang sama.

Langkah 3: Membagi ulang ulang (re-divide) interval pada langkah 2, apabila jumlah nilai linguistic yang dihasilkan masih besar dibanding jumlah rata-rata, maka nilai linguistic yang asli harus dibagi lagi menjadi setengah dari masing-masing.

Langkah 4: Menetapkan himpunan fuzzy (fuzzy sets) dalam semesta (universe) $U$.

Langkah 5: Fuzzyfikasi data historical dan buat Fuzzy Logical Relationship.

Langkah 6: Menetapkan bobot pada kelompok relasi fuzzy logic. Misal terdapat suatu urutan FLR yang sama,

$(t=1) A_{l} \rightarrow A_{l}$ dengan bobot 1 ,

$(t=2) A_{2} \rightarrow A_{l}$ dengan bobot 1 ,

$(t=3) A_{l} \rightarrow A_{l}$ dengan bobot 2 ,

( $t=4) A_{l} \rightarrow A_{l}$ dengan bobot 3 ,

$(t=5) A_{l} \rightarrow A_{l}$ dengan bobot 4 ,

Dalam hal ini t menyatakan waktu. Seperti Fuzzy Logical Relation ( $t=3)$ maka ketetapan bobot tertinggi adalah 3 , dimana kemungkinan titik tengah yang akan muncul selanjutnya lebih tinggi dari yang lain. Di sisi lain, Fuzzy Logical Relation $(t=1)$ ditetapkan bahwa bobot kurang dari 1, dimana kemungkinan titik tengah yang akan muncul selanjutnya lebih rendah dari yang lainnya. Sehingga dapat dibuat sebuah matrik tipe fluktuasi untuk semua Fuzzy Logical Relations.

Langkah 7: Kemudian mentransfer bobot tersebut ke dalam matrik yang telah di normalisasi $\left(W_{n}(\mathrm{t})\right.$ yang persamaan nya ditulis berikut:

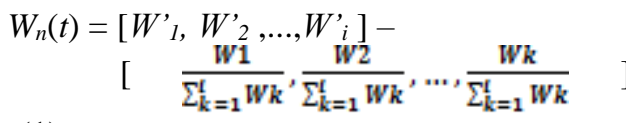

(1)

Langkah 8 : Penghitungan hasil peramalan. Untuk menghasilkan nilai peramalan, matrik pembobotan $(\mathrm{W}(\mathrm{t}))$ yang telah dinormalisasi menjadi $W_{n}(t)$ tersebut kemudian dikalikan dengan matrik defuzzifikasi yaitu $\mathrm{L}_{\mathrm{df}}=\left[\mathrm{m}_{1}\right.$, $\mathrm{m}_{2}, \ldots, \mathrm{m}_{\mathrm{k}}$ ] dimana $\mathrm{m}_{\mathrm{k}}$ adalah nilai tengah dari tiap-tiap interval. Cara untuk menghitung peramalannya adalah :

$F(t)=L_{d f}(t-1)$ o $W_{n}(t-1)$

Dimana $L_{d f}(t-1)$ adalah matrik defuzzyfikasi dan $W_{n}(t-1)$ adalah matrik bobot. 


\section{Metodologi}

Sistem akuisisi data dalam aplikasi prediksi konsentrasi gas $\mathrm{NO}_{2}$ ini menerapkan wireless sensor system yaitu sensor mendeteksi konsentrasi gas $\mathrm{NO}_{2}$ yang ada di udara dan diolah menjadi data time series yang disimpan pada local database pada microprocessor dengan menggunakan jaringan internet data historical konsentrasi gas $\mathrm{NO}_{2}$ dikirim ke web server dan disimpan pada online database untuk kemudian diprediksi.

Proses akuisisi data pada penelitian ini terintegrasi dengan Program Riset Unggulan Universitas Diponegoro Tahun 2014 pada riset Sistem Telemetri Monitoring Kualitas Udara Multichannel-Multistasion Menggunakan Teknologi Wireless Sensor Network Melalui Internet Broadband oleh Pusat Riset Sistem Informasi Industri Universitas Diponegoro dengan skema akusisi data konsentrasi Gas $\mathrm{NO}_{2}$ dapat dilihat pad Gambar 1.

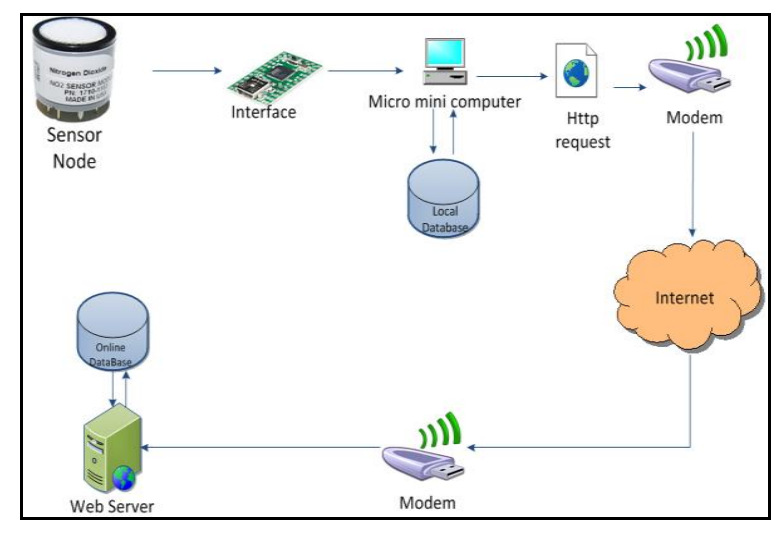

Gambar 1. Proses akuisisi data $\mathrm{Gas} \mathrm{NO}_{2}$

\section{Hasil dan Pembahasan}

Perhitungan forecasting konsentrasi gas $\mathrm{NO}_{2}$ disajikan sebagaimana Gambar 2, dengan melakukan dengan tahapan: a) Proses akuisisi data gas $\mathrm{NO}_{2}$. Akuisisi data dilakukan setiap 30 menit yang dimulai dari jam 00.30 dan diakhiri pada pukul 17.30 WIB dengan jumlah data sampel sebanyak 36 data seperti Tabel 1; b) Prediksi dengan mengimplementasikan algoritma Fuzzy Time Series Cheng dilakukan dengan langkah-langkah sebagai berikut :

1) Proses penentuan data aktual nilai terendah $\left(D_{\min }\right)$ dan nilai data tertinggi $\left(D_{\max }\right)$, untuk selanjutnya ditemukan $D_{1}$ dan $D_{2}$ sehingga diperoleh nilai himpunan semesta (universe discourse) $U=[0,30]$ seperti Gambar 3 .

2) Bagi nilai $U$ ke dalam beberapa interval $\left(u_{i}\right)$ yang sama, dalam penelitian ini pada perbagian pertama (first partition) diperoleh jumlah interval sebanyak 10 interval dengan rincian masing-masing interval sebagai berikut :

$$
\begin{aligned}
& u_{1}=[0,3], \quad u_{2}=[3,6], \quad u_{3}=[6,9], \quad u_{4}=[9,12], \\
& u_{5}=[12,15], \quad u_{6}=[15,18], \quad u_{7}=[18,21], \\
& u_{8}=[21,24], \quad u_{9}=[24,27] \text { dan } u_{10}=[27,30] .
\end{aligned}
$$

\begin{tabular}{|c|c|c|c|}
\hline No & $\begin{array}{c}\text { Waktu } \\
\text { Akuisisi }\end{array}$ & $\begin{array}{c}\text { Nilai } \\
\text { Konsentrasi }\end{array}$ & Fuzzyfikasi \\
\hline 1 & 00:30:00 & 5.1 & $\mathrm{~A} 2$ \\
\hline 2 & 01:00:00 & 8.1 & A3 \\
\hline 3 & 01:30:00 & 8.8 & A3 \\
\hline 4 & 02:00:00 & 9.5 & A4 \\
\hline 5 & 02:30:00 & 11.2 & A4 \\
\hline 6 & 03:00:00 & 12.1 & A5 \\
\hline 7 & 03:30:00 & 14 & A6 \\
\hline 8 & 04:00:00 & 13.2 & A5 \\
\hline 9 & 04:30:00 & 12.7 & A5 \\
\hline 10 & 05:00:00 & 13.8 & A6 \\
\hline 11 & 05:30:00 & 12.3 & A5 \\
\hline 12 & 06:00:00 & 12.8 & A5 \\
\hline 13 & 06:30:00 & 14 & A6 \\
\hline 14 & 07:00:00 & 13 & A5 \\
\hline 15 & 07:30:00 & 13.9 & A6 \\
\hline 16 & 08:00:00 & 15.3 & A7 \\
\hline 17 & 08:30:00 & 15.9 & A7 \\
\hline 18 & 09:00:00 & 16 & A7 \\
\hline 19 & 09:30:00 & 16.6 & A8 \\
\hline 20 & 10:00:00 & 16.8 & A8 \\
\hline 21 & 10:30:00 & 17 & A8 \\
\hline 22 & 11:00:00 & 17.5 & A8 \\
\hline 23 & 11:30:00 & 23.8 & A10 \\
\hline 24 & 12:00:00 & 19.4 & A9 \\
\hline 25 & $12: 30: 00$ & 20.5 & A9 \\
\hline 26 & 13:00:00 & 19.8 & A9 \\
\hline 27 & $13: 30: 00$ & 14.2 & A6 \\
\hline 28 & 14:00:00 & 14.7 & A6 \\
\hline 29 & $14: 30: 00$ & 15.1 & A7 \\
\hline 30 & 15:00:00 & 14.4 & A6 \\
\hline 31 & $15: 30: 00$ & 12.9 & A5 \\
\hline 32 & $16: 00: 00$ & 11.8 & A4 \\
\hline 33 & 16:30:00 & 9.3 & A4 \\
\hline 34 & $17: 00: 00$ & 8.6 & A3 \\
\hline 35 & $17: 30: 00$ & 3 & A1 \\
\hline 36 & 18:00:00 & 3 & $\mathrm{~A} 2$ \\
\hline
\end{tabular}

Tabel 1. Data aktual dan fuzzyfikasi

3) Dari pembagian pertama (first partition) masih terdapat jumlah data historical dalam masingmasing interval yang lebih besar dibanding dengan jumlah rata-rata yakni $1 / 2 \times 10=5$. Pada Gambar 3. terlihat bahwa $u_{10}$ yang memiliki jumlah keanggotaan sebanyak 0 yang akan dilakukan pembagian ulang (re-divide) menjadi setengahnya dan selanjutnya ditentukan nilai tengahnya (midpoint).

4) Penentuan himpunan fuzzy (fuzzy sets) dari data akuisisi dalam untuk menentukan keanggotan fuzzy sets $\left(A_{i}\right)$ dari himpunan semesta (universe of discourse) dengan hasil yakni :

$A_{1}=[0,3], \quad A_{2}=[3,6], \quad A_{3}=[6,9], \quad A_{4}=[9,12]$, $A_{5}=[12.13,5], A_{6}=[13.5,15], A_{7}=[15.16,5]$, $A_{8}=[16.5,18], \quad A_{9}=[18,21], \quad A_{10}=[21,24]$, $A_{11}=[24,27]$, dan $A_{12}=[27,30]$. 


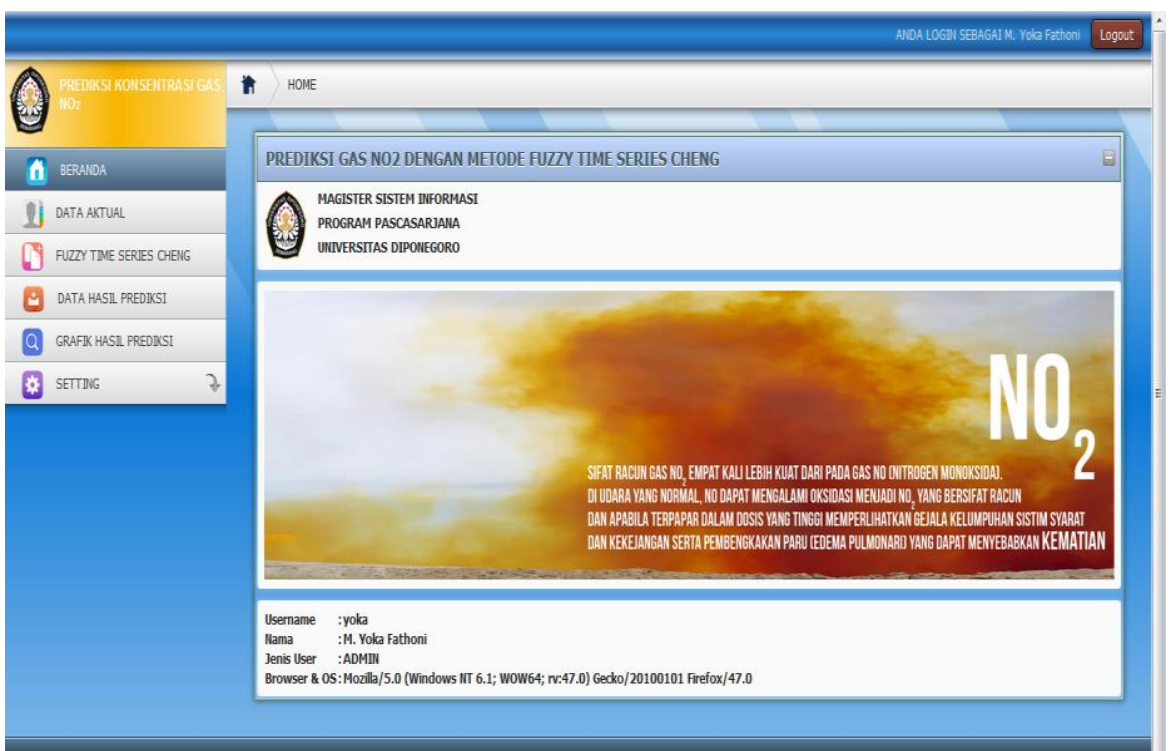

Gambar 2. Halaman beranda forecasting konsentrasi Gas $\mathrm{NO}_{2}$

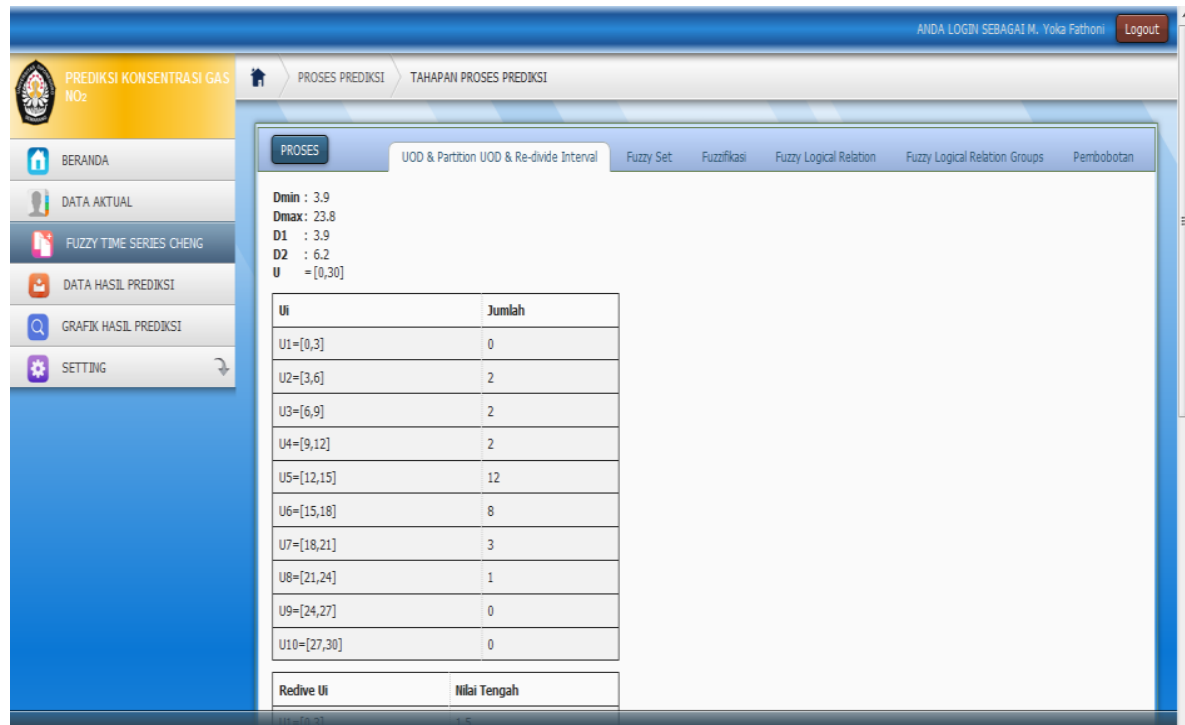

Gambar 3. Proses penetapan universe of discourse dan pembagian interval

5) Data historical dilakukan fuzzifikasi sebagaimana Tabel 1.

6) Dari hasil fuzzifikasi kemudian ditentukan Fuzzy Logical Relationship yaitu sebagai berikut

$\mathrm{A}_{1} \rightarrow \mathrm{A}_{2}, \quad \mathrm{~A}_{2} \rightarrow \mathrm{A}_{3}, \quad \mathrm{~A}_{3} \rightarrow \mathrm{A}_{4}, \quad \mathrm{~A}_{4} \rightarrow \mathrm{A}_{4}$, $\mathrm{A}_{4} \rightarrow \mathrm{A}_{5}, \quad \mathrm{~A}_{5} \rightarrow \mathrm{A}_{6}, \quad \mathrm{~A}_{6} \rightarrow \mathrm{A}_{7}, \quad \mathrm{~A}_{7} \rightarrow \mathrm{A}_{6}$, $\mathrm{A}_{6} \rightarrow \mathrm{A}_{6}, \quad \mathrm{~A}_{6} \rightarrow \mathrm{A}_{9}, \quad \mathrm{~A}_{9} \rightarrow \mathrm{A}_{9}, \quad \mathrm{~A}_{9} \rightarrow \mathrm{A}_{9}$, $\mathrm{A}_{9} \rightarrow \mathrm{A}_{10}, \quad \mathrm{~A}_{10} \rightarrow \mathrm{A}_{8}, \quad \mathrm{~A}_{8} \rightarrow \mathrm{A}_{8}, \quad \mathrm{~A}_{8} \rightarrow \mathrm{A}_{8}$, $\mathrm{A}_{8} \rightarrow \mathrm{A}_{8}, \quad \mathrm{~A}_{8} \rightarrow \mathrm{A}_{7}, \quad \mathrm{~A}_{7} \rightarrow \mathrm{A}_{7}, \quad \mathrm{~A}_{7} \rightarrow \mathrm{A}_{7}$, $\mathrm{A}_{7} \rightarrow \mathrm{A}_{6}, \quad \mathrm{~A}_{6} \rightarrow \mathrm{A}_{5}, \quad \mathrm{~A}_{5} \rightarrow \mathrm{A}_{6}, \quad \mathrm{~A}_{6} \rightarrow \mathrm{A}_{5}$, $\mathrm{A}_{5} \rightarrow \mathrm{A}_{5}, \quad \mathrm{~A}_{5} \rightarrow \mathrm{A}_{6}, \quad \mathrm{~A}_{6} \rightarrow \mathrm{A}_{5}, \quad \mathrm{~A}_{5} \rightarrow \mathrm{A}_{5}$, $\mathrm{A}_{5} \rightarrow \mathrm{A}_{6}, \mathrm{~A}_{6} \rightarrow \mathrm{A}_{5}, \mathrm{~A}_{5} \rightarrow \mathrm{A}_{4}, \mathrm{~A}_{4} \rightarrow \mathrm{A}_{4}, \mathrm{~A}_{4} \rightarrow \mathrm{A}_{3}$, $\mathrm{A}_{3} \rightarrow \mathrm{A}_{3}, \quad \mathrm{~A}_{3} \rightarrow \mathrm{A}_{2}, \quad \mathrm{~A}_{2} \rightarrow \mathrm{A}_{2}$.dan kemudian dibentuk kelompok hubungan logika fuzzy
(Fuzzy Logical

Groups/FLRG) yaitu :

Group $\mathrm{A}_{1} \rightarrow \mathrm{A}_{2}$.

Group $\mathrm{A}_{2} \rightarrow \mathrm{A}_{3}, \mathrm{~A}_{2}$.

Group $\mathrm{A}_{3} \rightarrow \mathrm{A}_{4}, \mathrm{~A}_{3}, \mathrm{~A}_{2}$.

Group $A_{4} \rightarrow A_{4}, A_{5}, A_{4}, A_{3}$.

Group $A_{5} \rightarrow A_{6}, A_{6}, A_{5}, A_{6}, A_{5}, A_{6}, A_{4}$.

Group $A_{6} \rightarrow A_{7}, A_{6}, A_{9}, A_{5}, A_{5}, A_{5}, A_{5}$.

Group $A_{7} \rightarrow A_{6}, A_{7}, A_{7}, A_{6}$.

Group $A_{8} \rightarrow A_{8}, A_{8}, A_{8}, A_{7}$.

Group $A_{9} \rightarrow A_{9}, A_{9}, A_{10}$.

Group $\mathrm{A}_{10} \rightarrow \mathrm{A}_{8}$.

Dari pengelompokan hubungan logika fuzzy (Fuzzy Logical Relationship Groups/FLRG) selanjutnya dibangun 
matrik tipe fluktuasi (fluctuation-type matrix) seperti Tabel 2.

7) Selanjutnya dilakukan pembobotan sesuai dengan frekuensi dari matrik tipe fluktuasi (fluctuation-type matrix), sebagai contoh dari Tabel 1 terdapat $P(t-1)=A_{10}$, maka kemungkinan prediksi untuk $P(t)$ adalah $A_{3}, A_{4}$ dan $A_{5}$ dari matrik pembobotan adalah $[1 / 4,2 / 4,1 / 4]$.

8) Perhitungan nilai prediksi.

Proses prediksi dilakukan menggunakan persamaan (2) dengan hasil pada web site sebagaimana Gambar 4 dan dengan grafik seperti ditunjukkan pada Gambar 5, serta secara mendetail pada Tabel 3. Sebagai contoh proses perhitungan dalam memprediksi konsentrasi gas $\mathrm{NO}_{2}$ pada jam 02.30, dilakukan dengan perhitungan sebagai berikut :

$$
\begin{aligned}
& F(\operatorname{Jam} 02.30)=L_{d f}(\operatorname{Jam} 02.30) \text { o } W_{n}(\operatorname{Jam} 02.00) \\
& F(\operatorname{Jam} 02.30)=\left[m_{1}, m_{2}, m_{3}\right] \text { o }\left[\frac{\mathbf{1}}{\mathbf{4}}, \frac{\mathbf{2}}{\mathbf{4}}, \frac{\mathbf{1}}{\mathbf{4}}\right] \\
& F(\operatorname{Jam} 02.30)=[7.5,10.5,12.5] \text { o }\left[\frac{\mathbf{1}}{\mathbf{4}}, \frac{\mathbf{2}}{\mathbf{4}}, \frac{\mathbf{1}}{\mathbf{4}}\right] \\
& F(\operatorname{Jam} 02.30)=6.15
\end{aligned}
$$

Tabel 2. Matrik tipe fluktuasi

\begin{tabular}{cccccccccccc}
\hline \multirow{2}{*}{$P(t)$} & \multicolumn{1}{c}{$A_{l}$} & $A_{2}$ & $A_{3}$ & $A_{4}$ & $A_{5}$ & $A_{6}$ & $A_{7}$ & $A_{8}$ & $A_{9}$ & $A_{10}$ & $A_{11}$ \\
\hline & 0 & 1 & 0 & 0 & 0 & 0 & 0 & 0 & 0 & 0 & 0 \\
$\mathrm{~A}_{1}$ & 0 & 1 & 1 & 0 & 0 & 0 & 0 & 0 & 0 & 0 & 0 \\
$\mathrm{~A}_{2}$ & 0 & 1 & 1 & 1 & 0 & 0 & 0 & 0 & 0 & 0 & 0 \\
$\mathrm{~A}_{3}$ & 0 & 0 & 1 & 2 & 1 & 0 & 0 & 0 & 0 & 0 & 0 \\
$\mathrm{~A}_{4}$ & 0 & 0 & 0 & 1 & 2 & 4 & 0 & 0 & 0 & 0 & 0 \\
$\mathrm{~A}_{5}$ & 0 & 0 & 0 & 0 & 4 & 1 & 1 & 0 & 1 & 0 & 0 \\
$\mathrm{~A}_{6}$ & 0 & 0 & 0 & 0 & 0 & 2 & 2 & 0 & 0 & 0 & 0 \\
$\mathrm{~A}_{7}$ & 0 & 0 & 0 & 0 & 0 & 0 & 1 & 3 & 0 & 0 & 0 \\
$\mathrm{~A}_{8}$ & 0 & 0 & 0 & 0 & 0 & 0 & 0 & 0 & 2 & 1 & 0 \\
$\mathrm{~A}_{9}$ & 0 & 0 & 0 & 0 & 0 & 0 & 0 & 1 & 0 & 0 & 0 \\
$\mathrm{~A}_{10}$ & 0 & 0 & 0 & 0 & 0 & 0 & 0 & 0 & 0 & 0 & 0 \\
$\mathrm{~A}_{11}$ & 0 & 0 & 0 & 0 & 0 & 0 & 0 & 0 & 0 & 0 & 0 \\
$\mathrm{~A}_{12}$ & 0 & & & 0 & & & & & &
\end{tabular}

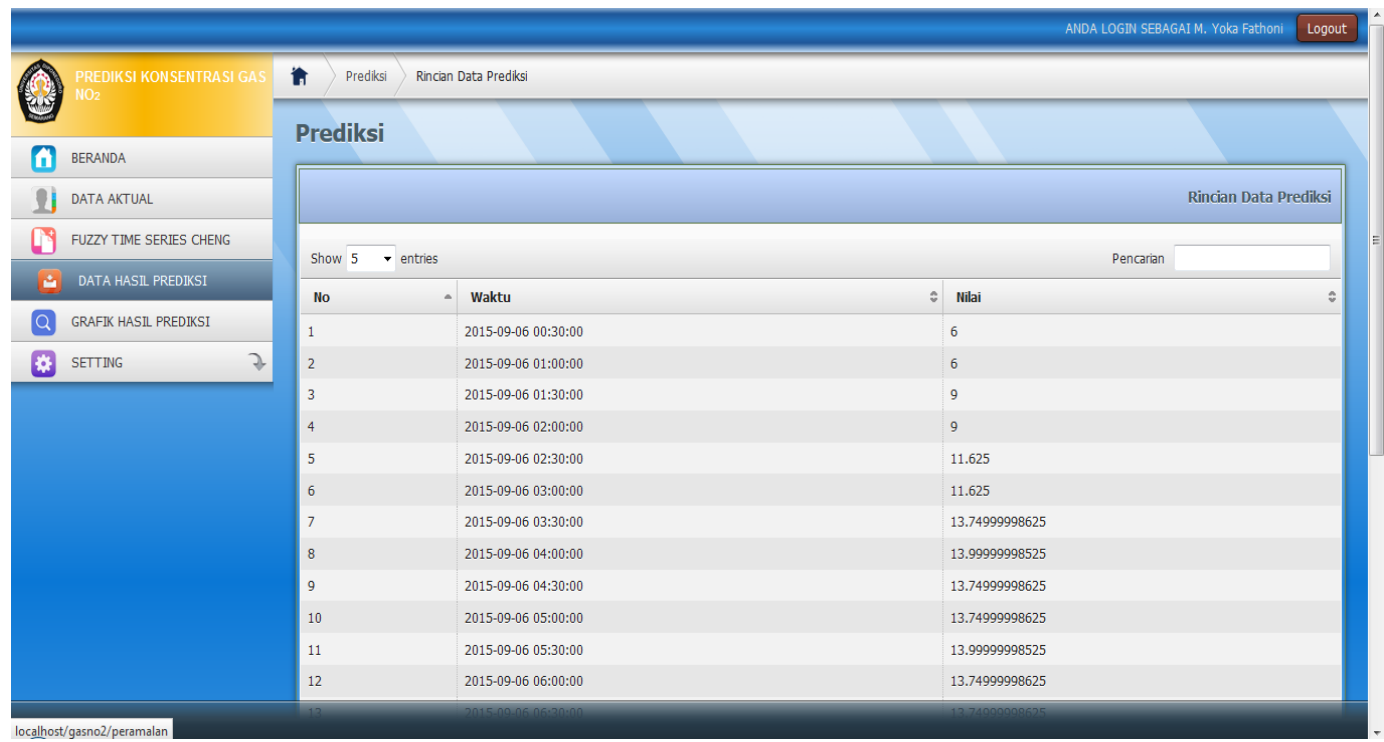

Gambar 4. Tampilan hasil prediksi 


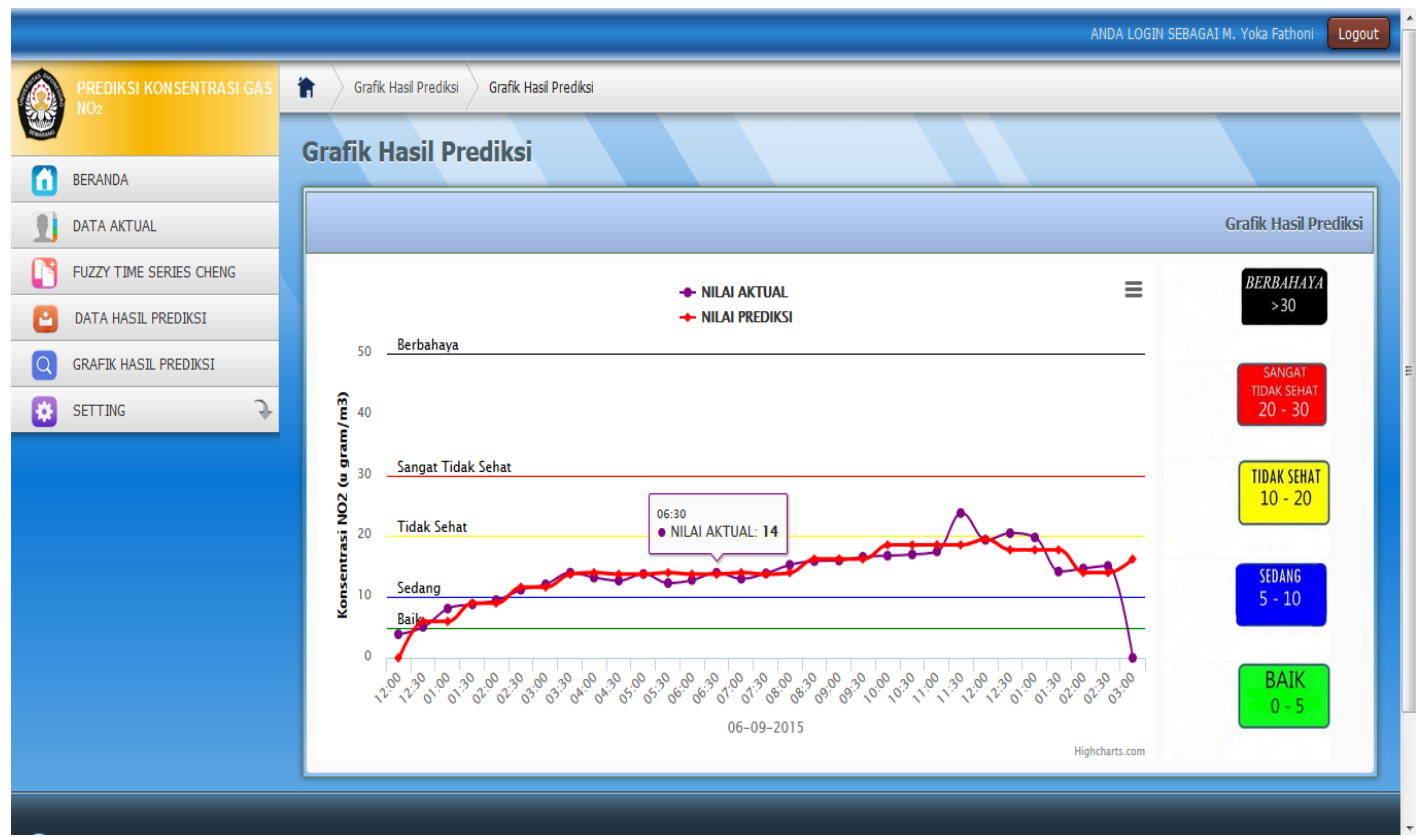

Gambar 5. Tampilan grafik hasil prediksi

Tabel 3. Hasil prediksi Gas $\mathrm{NO}_{2}$

\begin{tabular}{|c|c|c|c|}
\hline No & Waktu & Data Aktual & Hasil Prediksi \\
\hline 1 & 00:30:00 & 5.1 & -- \\
\hline 2 & 01:00:00 & 8.1 & 6.00 \\
\hline 3 & 01:30:00 & 8.8 & 7.50 \\
\hline 4 & 02:00:00 & 9.5 & 7.50 \\
\hline 5 & 02:30:00 & 11.2 & 10.31 \\
\hline 6 & 03:00:00 & 12.1 & 10.31 \\
\hline 7 & 03:30:00 & 14 & 13.29 \\
\hline 8 & 04:00:00 & 13.2 & 14.36 \\
\hline 9 & 04:30:00 & 12.7 & 13.29 \\
\hline 10 & 05:00:00 & 13.8 & 13.29 \\
\hline 11 & $05: 30: 00$ & 12.3 & 14.36 \\
\hline 12 & 06:00:00 & 12.8 & 13.29 \\
\hline 13 & 06:30:00 & 14 & 13.29 \\
\hline 14 & 07:00:00 & 13 & 14.36 \\
\hline 15 & 07:30:00 & 13.9 & 13.29 \\
\hline 16 & 08:00:00 & 15.3 & 14.36 \\
\hline 17 & 08:30:00 & 15.9 & 15.00 \\
\hline 18 & 09:00:00 & 16 & 15.00 \\
\hline 19 & 09:30:00 & 16.6 & 15.00 \\
\hline 20 & 10:00:00 & 16.8 & 16.88 \\
\hline 21 & $10: 30: 00$ & 17 & 16.88 \\
\hline 22 & 11:00:00 & 17.5 & 16.88 \\
\hline 23 & 11:30:00 & 23.8 & 16.88 \\
\hline 24 & 12:00:00 & 19.4 & 17.25 \\
\hline 25 & $12: 30: 00$ & 20.5 & 20.50 \\
\hline 26 & 13:00:00 & 19.8 & 20.50 \\
\hline 27 & $13: 30: 00$ & 14.2 & 20.50 \\
\hline 28 & 14:00:00 & 14.7 & 14.36 \\
\hline 29 & $14: 30: 00$ & 15.1 & 14.36 \\
\hline 30 & 15:00:00 & 14.4 & 15.00 \\
\hline 31 & $15: 30: 00$ & 12.9 & 14.36 \\
\hline 32 & $16: 00: 00$ & 11.8 & 13.29 \\
\hline 33 & $16: 30: 00$ & 9.3 & 10.31 \\
\hline 34 & 17:00:00 & 8.6 & 10.31 \\
\hline 35 & $17: 30: 00$ & 3 & 7.50 \\
\hline 36 & 18:00:00 & - & 7.50 \\
\hline \multicolumn{3}{|c|}{ RMSE . } & $2.87 \%$ \\
\hline
\end{tabular}

\section{Kesimpulan}

Forecasting dengan menerapkan permodelan Fuzzy Time Series Cheng yang melakukan pembagian ulang (Re-divide) dari hasil pembagian himpunan semesta pertama (first partition universal of discourse) dari masing-masing nilai interval dianggap dapat diterapkan untuk memprediksi konsentrasi Gas $\mathrm{NO}_{2}$, hal ini dapat dibuktikan dari hasil uji menggunakan jumlah data latih sebanyak 36 data dan diperoleh nilai error rata-rata sebesar $2.08 \%$ yang diukur menggunakan metode Root of Mean Squared Error ( RMSE ).

\section{Daftar Pustaka}

Aguilera, I., Basagana, X., Pay, M.T., Agis, D., Bouso, L., Foraster, M., Rivera, M., Baldasano, J.M., and Kunzli, N., 2014. "Evaluation of the CALIOPE air quality forecasting system for epidemiological research : The example of $\mathrm{NO}_{2}$ in the Province of Girona (Spain)" International Journal of Atmospheric Environment Vol. 72 (2013) 134-141

Chen, S.M., 1996. "Forecasting enrollments based on fuzzy time series - Fuzzy Sets and Systems" International Journal of Applied Science and Engineering Vol. 81 (1996) 311-319.

Chen, T.L., Cheng, H.C., dan Teoh, H.J., 2007. "Fuzzy time series based on sequence fo stock price forecasting" International Journal of Physica A Vol. 380, (2007) 3777-390

Cheng, C.H., Chen, T.L., dan Teoh, H.J., 2008. "Fuzzy time series based on adaptive 
expectation model for TAIEX forecasting" International Journal of Expert System with Application Vol. 34 (2008) 1126-1132.

Juhos, I., Makra, L., dan Toth B., 2008. "Forecasting of traffic origin $\mathrm{NO}$ and $\mathrm{NO}_{2}$ concentration by Support Vector Machine and neural network using Principal Component Analysis," International Journal of Simulation Modelling Practice and Theory, Vol.16 (2008) 1488-1502

Stojic, A., Maletic, D., Stojic S.S., Mijic,Z., dan Sostaric, A., 2015. "Forecasting of VOC emission from traffic and industry using classification and regression multivariate methods" International Journal of Science of the Total Environment, Vol.521-522 (2015) 1926

Song, Q., dan Chissom, B.S., 1993. Forecasting enrollments with fuzzy time series" International Journal of Fuzzy Set and System Vol. 54 (1993) 1-9
Spiegel, M.R., 1988. Teori dan Soal-soal Statistik Versi SI (Metrik), Erlangga, Jakarta.

Vanalakar, S., Patil, V., Harale, N.S., Vhanalakar, S.A., Gang, M.G., Kim, J.Y., Patil, P.S dan Kim, J.H., 2015. "Controlled growth of $\mathrm{ZnO}$ nanorod arrays via wet chemical route for $\mathrm{NO}_{2}$ gas sensor application". International Journal of Sensor and Actuator B:Chemical Vol.B221 (2015). 1195-1201.

Xihao, S., dan Yimin, L., 2008 Average-based fuzzy time series models for forecasting Shanghai compound index. International Journal of Modelling and Simulation Vol.4 pp (2008). 104-111.

Zhang, Y., ocquet, M., Mallet, V., Seigneur, C., dan Baklanov, A., 2012. "Real-time air quality forecasting, part II: State of the science, current research needs, and future prospects" International Journal of Atmospheric Environment Vol. 60 (2012) 656-676. 